\title{
CEO CHARACTERISTICS, OWNERSHIP CONCENTRATION AND CORPORATE SOCIAL RESPONSIBILITY DISCLOSURE
}

\author{
NICOLAS BAYU KRISTIAWAN \\ Sanata Dharma University, JI. Mrican Baru, Mrican, Caturtunggal, Depok, Sleman, Yogyakarta, Indonesia \\ nicolasbayu@usd.ac.id
}

\begin{abstract}
The study aims at investigating the influence of CEO characteristics on Corporate Social Responsibiliy (CSR) Disclosure and the moderation effect of ownership concentration on the influence of CEO characteristics on CSR disclosure. The sample consist of 93 companies listed in the Indonesian Stock Exchange from 2013 to 2015. The data of CEO characteristics were gathered from the economics and business-related educational background, the functional experience, the gender and the age in the annual reports of the sampled companies and other relevant sources. On the other hand, the data of ownership concentration and of control variable such as company size, financial performance, financial leverage and audit quality were gathered from the BvD Osiris database. The data of CSR disclosure were gathered by means of checklist method on the annual reports of these companies based on the GRI G4 index. The results of the study show that the output functional experience characteristic has positive influence on the level of CSR disclosure. In addition, the moderation test from the ownership concentration on the influence of CEO characteristics on CSR disclosure do not show significant results.
\end{abstract}

Keywords: CEO characteristics, ownership concentration csr disclosure, upper echelon theory

Abstrak: Penelitian bertujuan untuk menguji pengaruh karakteristik direktur utama terhadap pengungkapan tanggung jawab sosial perusahaan dan menguji moderasi konsentrasi kepemilikan pada pengaruh karakteristik direktur utama terhadap pengungkapan tanggung jawab sosial perusahaan. Sampel yang digunakan adalah 93 perusahaan yang terdaftar di BEI tahun 2013-2015. Data pengungkapan tanggung jawab sosial perusahaan diambil dengan menggunakan metode check list pada laporan tahunan perusahaan berdasarkan pada indeks GRI G4. Data karakteristik direktur utama yaitu latar belakang pendidikan ekonomi \& bisnis, pengalaman fungsional, gender dan usia diambil dari laporan tahunan perusahaan dan sumber-sumber lain yang relevan, sedangkan data konsentrasi kepemilikan dan variabel kontrol seperti ukuran perusahaan, kinerja keuangan, financial leverage dan kualitas audit diperoleh dari database Bvd Osiris. Hasil dalam penelitian ini menunjukan bahwa karakteristik pengalaman fungsional output berpengaruh positif terhadap tingkat pengungkapan tanggung jawab sosial perusahaan. Hasil pengujian moderasi konsentrasi kepemilikan pada pengaruh karakteristik direktur utama terhadap pengungkapan tanggung jawab sosial perusahaan tidak menemukan hasil yang signifikan.

Kata kunci: Karakteristik direktur utama, konsentrasi kepemilikan, dan pengungkapan tanggung jawab sosial perusahaan, upper echelon theory 


\section{INTRODUCTION}

Corporate Social Responsibility (CSR) has increasingly been the main attention to both the academicians and the practitioners. The statement is apparent from the increasing number of studies on CSR within the last few years (Caroll, Primo, \& Ritcher, 2016; Wang, Tong, Takeuchi, \& George, 2016) and the increasing attention of investors, multistakeholder groups, local companies, multinational companies and even governments toward CSR (Boulouta \& Pitelis, 2014; Chapple \& Moon, 2005; Holder-Webb, Cohen, Nath, \& Wood, 2009; Muttakin \& Khan, 2014; Park \& Ghauri, 2014). However, the studies that have been conducted up to date still focus on the effects of the organizational and the institutional factors such as, company size, economics performance and financial leverage. The effects of TMT Characteristics toward CSR still has received little attention in the previous studies. It becomes important because TMT is playing important role to influence company strategic decision, including CSR policy (Kyun, Oh, Hyun, Myoung, \& Jang, 2015). In addition, organizations are a reflection of their top management (Hambrick, 2007; Hambrick \& Mason, 1984)

Several studies that have been conducted strive to study the influence of the top management characteristics on the CSR (Fabrizi, Mallin, \& Michelon, 2014; S. K. Huang, 2012; Manner, 2010; Oh, Li, \& Park, 2016; Slater \& Dixon-Fowler, 2010; Sun \& Rakhman, 2013). The results of these studies show that the CEO who has the Economics and Business-related educational background (Economics and MBA) display longer and wider tenure while the female CEO will display better performance on the domain of social responsibility. Despite the results, these studies have been conducted in the context of developed countries, which has better corporate governance and CSR in comparison to the developing countries. Therefore, several questions in relation to the conduct of similar studies in the context of developing countries, such as Indonesia for example, might appear and some of these questions might be as follows: (a) What if the test is performed in the context of developing countries, specifically Indonesia, which possess the concentrated ownership structure; and (b) What if the major stakeholders dominate the decision-making process of the CEO in relation to the CSR ? Departing from the two hypothetical questions, through the study the researcher would like to test the influence of CEO characteristics and the concentrated ownership structure on the CSR in the context of developing countries, specifically Indonesia

Specifically, within the study the researcher would like to test the moderation effect of the concentrated ownership structure toward the influence of CEO characteristics on CSR disclosure in Indonesia since most of the companies in Indonesia are of concentrated ownership (Carney \& Hamilton-Hart, 2015; Claessens, Djankov, \& Lang, 2000). Within the companies that have the concentrated ownership, the influence of management characteristics on the CSR will decrease because the major stakeholders will dominate the decision-making process and this situation will benefit the major stakeholders. The reason is that the major (concentrated) stakeholders tend to exert strong influence and will interfere the policy-making process within the company in order to maximize their personal profit (Dam \& Scholtens, 2013; Dias, Rodriguez, \& Craig, 2017; Jaggi \& Tsui, 2007; Peng \& Yang, 2014). There is a tendency that the conflict of agency that might have occured is caused by the huge stake ownership in relation to the CSR. The bigger the size of ownership that the stakeholders have within a company, the smaller the tendency that the stakeholders will implement the CSR (Dam \& Scholtens, 2013).

Then, the results of the study are expected to give contributions to the efforts of improving the conduct of CSR in Indonesia. The 
first contribution is related to the appointment of CEO (CEO). CEO might be appointed based on the characteristics that might improve the CSR. In relation to the statement, the results of the present study show that one of the top management characteristics, namely the output functional characteristics, has positive influence on the CSR, while the other top management characteristics, namely the Economics and Business-related educational background, age, and gender, does not have any influence on the CSR. The CEO who has the output functional experience will tend to disclose more corporate social responsibilities. This situation might happen because the output functional experience that has been attained on the field will shape the characters of the CEO better in comparison to the other characteristics such as the educational background. Then, the second contribution is related to the formulation of the policy that regulates the ownership structure of the company. The ownership structure of the company might be limited to the dispersed ownership under the objective of avoiding the concentrated ownership that will influence the decision-making process in relation to the CSR.

In this section, the researcher would like to review all theories that will be implemented into the conduct of the study. The theories that will be reviewed are Upper Echelons Theory, Educational Background and CSR Disclosure, Functional Experience and CSR Disclosure, Gender and CSR Disclosure, Age and CSR Disclosure and CEO Characteristics and CSR Disclosure. Through the elaboration of the theory, the researcher would also like to develop the hypotheses for the conduct of the study. The theories and the hypotheses development might be consulted in the following sub-sections.

\section{Upper Echelons Theory}

Wood (1991) states that in analyzing the CSR there should be institutional analysis, organizational analysis and individual-level analysis. Most of the studies on the CSR still focus on the organizational and institutional analysis such as company size (BaumannPauly, Wickert, Spence, \& Scherer, 2013; Chang, Oh, Jung, \& Lee, 2012; Haniffa \& Cooke, 2005; Muttakin \& Khan, 2014; Udayasankar, 2007), economic performance (Kansal, Joshi, \& Batra, 2014; Muttakin \& Khan, 2014; Oeyono, Samy, \& Bampton, 2011) and financial leverage (Kansal et al., 2014; Khlif \& Souissi, 2010; Muttakin \& Khan, 2014) which will influence the CSR of a company. Hambrick \& Mason (1984) state in upper echelons theory that organizational outcomes, namely the strategy selection and the performance level, are predicted partially by the characteristics of the managerial background. Furthermore, Hambrick, (2007) has found that several managerial characteristics will influence the strategic decisions of a company and its performance. Similarly, Carpenter, Geletkancz, \& Sanders (2004) concludes that the model in the upper echelons theory has been valid for implementation into the business studies with different contexts. The statement implies that the influence of managerial characteristics on the strategic decisions and the company performance has been validly proven. Furthermore, Carpenter et al., (2004) suggest that there should be further studies on a different area namely the CSR area and the business ethics. In relation to the suggestion, Hooghiemstra (2000) argues that the activities of corporate social responsibilities is an embodiment of managerial impression toward the company, or it might be concluded that the CSR of a company is a managerial initiative that has been influenced by the characteristics of the managerial background.

In the Upper Echelons Theory, Hambrick \& Mason (1984) classify the characteristics of managerial background that explains the organizational outcomes as follows: (1) age; (2) functional experience; (3) other career experiences; (4) formal education; (5) socioeconomic background; (6) financial position; and (7) group heterogeneity. With 
regards to the classification, in the study the researcher would like to focus on the influence of economic and business educational background, functional experience, gender and, age of the CEO (CEO) on the CSR Disclosure (S. K. Huang, 2012; Manner, 2010).

\section{Economics and Business-Related Educational Background and Corporate Social Responsibility Disclosure}

The first CEO Characteristic that will be tested is the Economics and Business-Related Educational Background. Specifically, within the study the researcher would like to test the influence of Economics and Business-Related Educational Background on the CSR Disclosure. Frank, Gilovich, \& Regan (1993) state that educational background will shape the values and the belief of an individual. Within his experiment, Frank et al. (1993) have found that the university students who have taken the Micro Economic Course for one semester will not tend to experience a dilemma of ethics when they deal with the social problems and will not be reluctant to work with other university students. This finding shows that the educational process in Economics and Business that has been attended will shape the values and the belief of the university students as having been reflected by their behaviours within the experiment. The university students within the experiment tend to be reluctant to work with the other university students, will not experience a dilemma of ethics when they deal with the social problems and, instead, will tend to prioritize the individual interest with the objective of maximizing the personal benefits rather than contemplating on the social problems (Boone, Brabander, \& Witteloostuijn, 1999; B. Frank \& Schulze, 2000; Jones, Agle, \& Jenifer Ehreth, 1990; Selten \& Ockenfels, 1998). The educational process in Economics and Business strives to maximize the profit of the company rather than paying attention to the social problems. Departing from this point of view, in the study the researcher will take an opposition by looking forward to a different aspect. Through the conduct of the present study, the researcher would like to assert that the perspective of the stakeholders and the problems of CSR have gained huge attention among the students in the faculty of Economics and Business (Alonso-Almeida, Fernández De Navarrete, \& Rodriguez-Pomeda, 2015; Kleinrichert, Tosti-Kharas, Albert, \& Eng, 2013; $\mathrm{Ng} \&$ Burke, 2010; Nicholas \& Sacco, 2017; Wong, Long, \& Elankumaran, 2009). The reason is that the concept of company continuity and CSR have been taught in the universities, especially in the developed countries.

Within the context of developing countries, the mastery on the concept of the CSR and the presence of the attention toward the CSR among the companies and the stakeholders have been low. The companies in Indonesia still take side on the shareholders rather than the stakeholders and the CSR is still perceived as a less formal and a philanthropic aspect with less attention (Jain, Aguilera, \& Jamali, 2014; Jamali \& Karam, 2016; Jamali \& Neville, 2011). Similarly, the perception of the students in the faculty of Economics and Business within the developing countries imply that the CSR is still perceived as a philanthropic aspect and therefore these students tend to prioritize the company (Schmidt \& Cracau, 2015). Based on these findings, the researcher would like to argue that the CEOs who are from the Economics and Business-related educational background in Indonesia tend to not disclose the CSR. The CEO in Indonesia tend to maximize the profit and prioritize the company interest rather than disclose the CSR. Then, departing from the elaboration on this sub-section, the researcher would like to propose the first hypothesis as follows:

H1: Economics and Business-related Educational Background of the CEO has negative influence on CSR Disclosure 


\section{Functional Experience and Corporate Social Responsibility Disclosure}

The second CEO Characteristic that will be tested is the Functional Experience. Functional Experience refers to the experience that an individual has attained in a certain domain for years. Functional Experience will shape the perception of an individual when the individual views a problem. Hambrick \& Mason (1984) in Upper Echelons Theory state that in designing a job orientation the top management (CEO) will base the development of the job orientation on the functional experience that he or she has attained. The background of the Functional Experience has been proven to display direct influence on objective orientation, problem definition manner, informationprocessing activity and company strategy selection; in turn, the influence of the background on these aspects will impact the financial performance of the given company (Beal \& Yasai-Ardekani, 2000; Custódio \& Metzger, 2014; Ritchie \& Eastwood, 2006; Walsh, 1988). One of the managerial decisions and strategies is the decision on the CSR disclosure.

Furthermore, within the Upper Echelons Theory (Hambrick \& Mason, 1984) classify the Functional Experience into two categories namely the Output Functional Experience and the Throughput Functional Experience. The Output Functional Experience consists of individual experiences in the domain of marketing, sale, product research and development and also in the domain that will have more relationships with the stakeholders. On the other hand, the Throughput Functional Experience consists of individual experiences in the domain of production and engineering and accounting and also in the domain that emphasized the job efficiency and the internal aspect of the company or the domain that does not display many relationships with the stakeholders but instead display more relationships with the shareholders. The Output Functional Experience and the Throughput
Functional Experience are two different matters. Individuals who work with the basis of either Output Functional Experience or Throughput Functional Experience will tend to implement the orientation and the policy within the company and the job environment under different manner. A director with the background of Output Functional Experience as a stakeholder will tend to understand the desire of the stakeholders (Manner, 2010). On the other hand, a director with the background of Throughput (Shareholder-Oriented) Functional Experience will tend to be irresponsive toward the stakeholders and will tend to think more about how to improve the company performance. Through the study, the researcher has categorized the Functional Experience as a CEO and a Commissary into the Throughput Functional Experience because the CEO and the Commissary are rarely in direct opposition to the stakeholders and, instead, the CEO and the Commissary will think more about how to improve the company performance. The researcher deems important to add the classification of the experiences of both the CEO and the Commissary because many CEOs and Commissaries in Indonesia have attained their functional experiences directly without going through the path of the career degree. The reason is that there is a kinship within the companies in Indonesia. In relation to the CSR, a CEO with the Output Functional Experience as his or her background will tend to understand better the desires of the stakeholders. As a result, such CEO will perform more CSR Disclosures. This statement is supported by the results of the study by Manner, (2010), which show that the CEO with the Stakeholder (Output) Functional Experience will display better performance in relation to the CSR Disclosure. Afterward, departing from the elaboration in this sub-section, the researcher would like to propose the second hypothesis in the study as follows: 
$\mathrm{H}$ 2: The Output Functional Experience of the CEO has positive influence on the CSR Disclosure.

\section{Gender and Corporate Social Responsibility Disclosure}

The third CEO Characteristic that will be tested is the Gender. Through the study, the researcher would like to test the influence of Gender on the CSR Disclosure. Gender is still implemented as the CEO characteristic although Hambrick \& Mason (1984) does not input gender into one of the managerial characteristics that will influence the company decision and strategy. However, the results of several studies support that Gender might influence company outcomes. Carpenter et al. (2004) argue that Gender should be given attention in the studies of Upper Echelon (Top Management). Then, in their study Post, Rahman, \& Rubow (2011) has found that women tend to care more about the environmental problems in comparison to men since women play significant role in nurture and reproduction. In relation to social responsibility, the Female CEO will display higher level of social care; as a result, the Female CEO will display more CSR Disclosures. This argument has been supported by the results of a study by Manner (2010) and a study by Alonso-Almeida et al. (2015). The two studies have found that the Female CEOs care more about the social responsibility problems and tend to display higher number of CSR Disclosures. Departing from the elaboration in this sub-section, the researcher would like to propose the third hypothesis as follows:

H3: The Female CEO has positive influence of the CSR Disclosure.

\section{Age and Corporate Social Responsibility Disclosure}

The fourth CEO Characteristic that will be tested is Age. (H. W. Huang, Rose-Green, \& Lee, 2012). (Post et al., 2011) state that Age consistently correlates to the moral assessment of an individual. The older an individual is, the higher the individual's moral assessment will be (Forte, 2004; S. K. Huang, 2012; McCabe, Ingram, \& Dato-On, 2006). Then, the moral assessment of an individual might be related to the CSR of a company. Individuals who have higher moral assessment will give more attention to the problems in the neighbourhood and the society. The older CEOs will tend to disclose more Corporate Social Responsibilities. The reason is that the older CEOs have higher moral assessment. However, the arguments by several researchers state that younger individuals might have better knowledge and assessment toward the neighbourhood in comparison to the older individuals and thus these younger individuals will give more attention to the problems in the neighbourhood (Diamantopoulos, Schlegelmilch, Sinkovics, \& Bohlen, 2003; Klineberg, McKeever, \& Rothenbach, 1998; L.A. Philips, 1999).

In the present study, the researcher would like to state that older CEOs will disclose more Corporate Social Responsibilities in comparison to younger CEOs. The reason is that there are differences on the risk preference and the policy of each CEO. Hambrick \& Mason (1984) in Upper Echelon Theory explain that the older CEOs tend to implement less risky policies. In other words, the older CEOs will run their company under more conservative manner (Sundaram \& Yermack, 2007). On the other hand, the younger CEOs tend to implement more risky policies in order to increase the profitability of their company. In other words, the younger CEOs tend to prioritize the improvement of company performance and profitability in order to exhibit their self-achievement rather than implementing the Corporate Social Responsibility-related policies. Then, departing from the elaboration in this sub-section, the researcher would like to propose the fourth hypothesis as follows: 
H4: The Age of Chief Executive Director has positive influence on the CSR Disclosure

\section{CEO Characteristics, Ownership Concentration and Corporate Social Responsibility Disclosure}

Through the conduct of the study, the researcher would like to expand the study by Manner (2010) \& S. K. Huang, (2012) by testing most of the companies in Indonesia that have the Concentrated-Type Ownership Structure (Carney \& Hamilton-Hart, 2015; Claessens et al., 2000). Specifically, through the present study the researcher would like to test the moderation of the Ownership Concentration toward the influence of the CEO Characteristics on the CSR Disclosure. Jaggi \& Tsui (2007) state that the shareholders who have huge (concentrated-type) ownership expose the possibility to interfere the management of the company in order to maximize their personal interest. Shleifer \& Vishny (1997) state that the major shareholder might force their personal preference; in fact, the personal preference of the major shareholders might be in contradiction to the personal preference of the minor shareholders and the management of the company. Then, the results of the studies that test the Ownership Concentration show that shareholders with concentrated-type ownership will tend to dominate the decisionmaking process and this action will benefit the major shareholders (Choi, Lee, \& Park, 2013; Dam \& Scholtens, 2013; Dias et al., 2017; Faccio, Lang, \& Young, 2001; Jaggi \& Tsui, 2007; Kim \& Yoon, 2008; Leuz, Nanda, \& Wysocki, 2003; Peng \& Yang, 2014; Varma, Patel, \& Naidu, 2009). Within the company with Concentrated-Type Ownership Structure, the decision of the CEO will be influenced by the major shareholders in order that the interest of the major shareholders might be maximized.

In relation to the Corporate Social Responsibility, the decision of CEO to disclose the CSR is influenced by the interest of the major shareholders. Dam \& Scholtens (2013) conclude that the bigger the Ownership of the shareholders within a company the smaller the tendency of the shareholders to disclose the CSR will be. The reason is that the major shareholders tend to prioritize the maximization of the company's profit and performance rather than the CSR Disclosure. The results from several studies show that ownership concentration has negative influence on corporate social responsibility (Dam \& Scholtens, 2013; Dias et al., 2017; Reverte, 2009).

In a company that has the Concentrated-Type Ownership Structure, the CEOs that weaken the CSR Disclosure will be strengthened by the domination of the major shareholders. The reason is that there has been alignment effect or the similarity of interest between the major shareholders and the CEOs namely that both of them prioritize the company performance rather than the CSR disclosure. As a result, the researcher would like to propose the first alternative of the fifth hypothesis as follows:

H5a: Ownership Concentration strengthens the negative influence of Economic and Business-related Educational Background of the CEO on the CSR Disclosure.

On the contrary, the CEO Characteristics that strengthen the CSR Disclosure will be weakened by the major shareholders who have different interest than the CEOs. The reason is that the CEOs put higher priority on the CSR whereas the major shareholders put higher priority on the maximization of the company's profit and performance. As a result, the researcher would like to propose the second, the third and the fourth alternative as follows:

$\mathrm{H} 5 \mathrm{~b}$ : Ownership Concentration weakens the positive influence of the Functional 


\section{Experience of the CEO on the CSR Disclosure}

$\mathrm{H} 5 \mathrm{c}$ : Ownership Concentration weakens the positive influence of the Female CEO on the CSR Disclosure.

H5d : Ownership Concentration weakens the positive influence of the Age of the CEO on the CSR Disclosure

Departing from the five hypotheses that have been developed, the researcher would like to design the research framework as follows. Independent Variables:

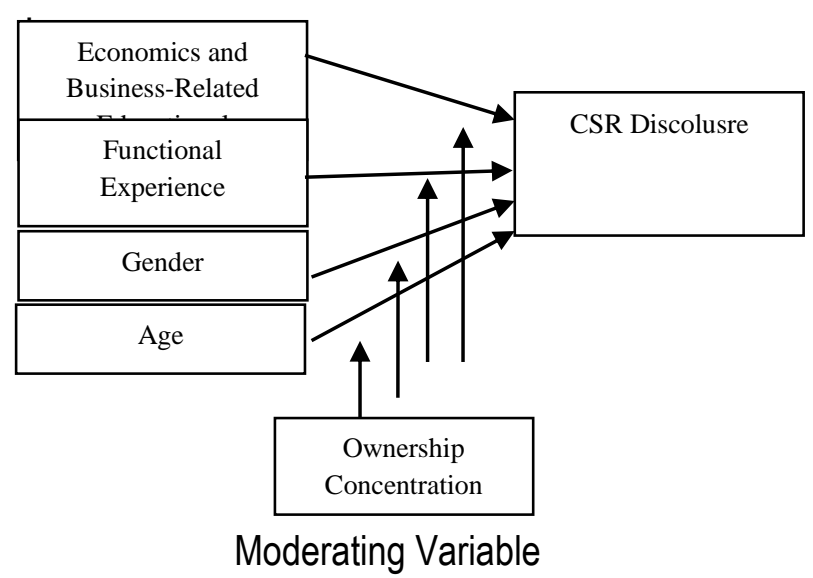

Figure 1 Research Framework

\section{RESEARCH METHODS}

The samples that had been selected in the study were the companies that had been registered in the Indonesian Stock Exchange from 2013 until 2015. The sample selection started from 2013 because the GRI G4 indicators that had been implemented in the study was issued in 2013. Then, 2015 was decided as the end of the observation year because the data of the selected companies that had been issued until 2015 were the latest and the most complete data. In other words, the data of the companies that had been registered in the Indonesian Stock Exchange until 2016 and 2017 had not been complete yet. Then, within the study the researcher involved one dependent variable, five dependent variables and four control variables. The dependent variable was the level of CSR Disclosure. Next, the independent variables were Economics \& Business-Related Educational Background, Functional Experience, Gender, Age and Ownership Concentration. Ownership Concentration served as the moderating variable within the influence of the CEO Characteristics on the CSR Disclosure. Last but not the least, the control variables were Company Size, Leverage, Economic Performance and Audit Quality..

In testing the first hypothesis up to the fourth hypothesis, the researcher implemented the multiple linear regressions analysis with the following regression mode:

Model 1 (hypothesis 1 until hypothesis 4) CSRD $=\beta_{0}+\beta_{1} E D U+\beta_{2} F U N G E X P+\beta_{3} F E M+\beta_{4}$ Age $+\beta_{5} S I Z E+\beta_{6} L E V+\beta_{7} R O A+\beta_{8} A U D$ $+\varepsilon$

On the other hand, in testing the fifth hypothesis, the researcher implemented the regression analysis with moderation. The regression model that had been designed was divided into four sub-models in order to test the influence of the moderation by the ownership concentration on each CEO characteristic:

Model 2 (Hypothesis 5a)

CSRD $=\beta_{0}+\beta_{1} E D U+\beta_{2} O W C+\beta_{3} O W C^{*} E D U+$ $\beta_{4} S I Z E+\beta_{5} L E V+\beta_{6} R O A+\beta_{7} A U D+\varepsilon$

Model 3 (Hypothesis $5 b$ )

CSRD $=\beta_{0}+\beta_{1}$ FUNGEXP $+\beta_{2}$ OWC + $\beta_{3} O W C^{*}$ FUNGEXP $+\beta_{4} S I Z E+\beta_{5} L E V+\beta$ ${ }_{6} R O A+\beta_{7} A U D+\varepsilon$

Model 4 (Hypothesis $5 c$ )

CSRD $=\beta_{0}+\beta_{1}$ FEM $+\beta_{2} \mathrm{OWC}+\beta_{3} \mathrm{OWC}$ FEM $^{*}$ $\beta_{4} S I Z E+\beta_{5} L E V+\beta_{6} R O A+\beta_{7} A U D+\varepsilon$

Model 5 (Hypothesis $5 \mathrm{~d}$ )

$C S R D=\beta_{0}+\beta_{1} A G E+\beta_{2} O W C+\beta_{3} O W C^{*} A G E+$ $\beta_{4} S I Z E+\beta_{5} L E V+\beta_{6} R O A+\beta_{7} A U D+\varepsilon$

The CSR Disclosure was measured by using the indicators from the Global Reporting Initiative (GRI) G4. The GRI Index has been one of the reliable measures for assessing the 
CSR Disclosure. These measures have been complete and have also been widely implemented in the studies about CSR (Fernandez-Feijoo, Romero, \& Ruiz, 2014; KPMG, 2011). For the GRI G4 Index, there have been 91 items of CSR report and these items are divided into three categories namely Economics (9 items), Environment (34 items) and Social (48 items). The social items are broken down again into several sub-items namely Employment, Human Rights and Product Responsibility. Every item of CSR Disclosure will be scored 1 if the CSR Disclosure is reported and will be scored 0 if the CSR is not disclosed. Then, the score of each item should be summed in order to attain the overall score of CSR Disclosure. The following is the formula for calculating the score of CSR disclosure).

Note:

$$
\text { CSRDI }_{\mathrm{j}}=\frac{\sum \mathrm{x}_{\mathrm{j}}}{\mathrm{n}_{\mathrm{j}}}
$$

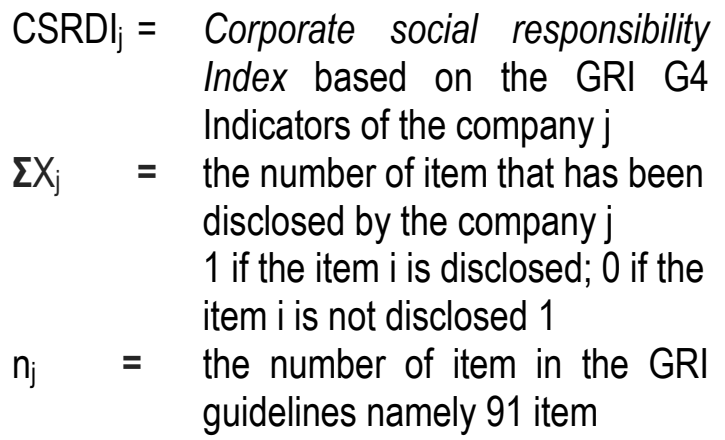

Economics and Business-Related Educational Background (EDU) of the CEO should be scored 1 if the CEO had been from the Economic and Business-Related Educational Background and should be scored 0 if the CEO had not been from the Economic and Business-Related Educational Background. Within the study, the Economic and BusinessRelated Educational Background consisted of the following departments: (1) Economics Science, (2) Accounting; (3) Management; (4) Master of Business Administration (MBA); (5) Master of Management; and (6) Profession of Accounting. Then, the Functional Experience of the CEO (FUNCEXP) was classified into two categories namely the Output (StakeholderOriented) Functional

Experience and the Throughput (ShareholderOriented) Functional Experience (Hambrick \& Mason, 1984; Manner, 2010). The Functional Experience of the CEO should be scored 1 if the CEO had the Output Functional Experience and 0 if the CEO had the Throughput Functional Experience. Next, the Gender of the CEO (FEM) should be scored 1 if the CEO was Female and 0 if the CEO was Male. Last but not the least, the Age of the CEO (AGE) was attained from the annual report of the sample companies. On the other hand, the data on the Ownership Concentration (OWC), Company Size (SIZE), Leverage (LEV), Economic Performance (ROA) and Audit Quality (AUD) were attained from the BvD Osiris database.

\section{RESULTS AND DISCUSSIONS}

The data are attained from the samples that have been selected in the study, namely the companies that have been registered in the Indonesian Stock Exchange from 2013 until 2015. The Type of Industry is based on the NAICS Code and the NAICS Code serves as the basis for coding the company. The NAICS Code itself consists of the code Number 1 until the code Number 9. Table 1 shows that the companies that have been registered in the Indonesian Stock Exchange are the Code 1 Company until the Code 7 Company and most of the companies are from the manufacture industry. Then, the total sampled companies are 93 companies with the number of observation 279 company year. The highest mean score of CSR Disclosure is earned by the companies of Mine and Construction namely 0.1352 , while the lowest mean score of CSR Disclosure is earned by the companies of Health, Hospitality and Restaurant Industry namely 0.0520 . The data on the CSR Disclosure are attained from the annual report of the sampled companies based on the GRI 
G4 Index, while the data on the CEO characteristics and the data on the ownership concentration are attained from the annual report of each sampled company and other relevant sources. On the contrary, the data on the control variables are attained from the BvD Osiris database.

Tabel 1 Descriptive Statistics of Research Variables

\begin{tabular}{lcccc}
\hline Variable & Minimum & Maximum & Average & $\begin{array}{l}\text { Deviation } \\
\text { Standard }\end{array}$ \\
\hline CSRD & 0,01 & 0,22 & 0,083 & 0,05077 \\
EDU & 0,00 & 1,00 & 0,6523 & 0,47709 \\
FUNGEXP & 0,00 & 1,00 & 0,2115 & 0,40908 \\
FEM & 0,00 & 1,00 & 0,0251 & 0,15668 \\
AGE & 30 & 76 & 52,19 & 8,82828 \\
OWC & 0,09 & 0,95 & 0,4937 & 0,20556 \\
Ln_SIZE & 7,83 & 14,73 & 12,099 & 1,49455 \\
ROA & $-0,3$ & 0,39 & 0,0348 & 0,09062 \\
LEV & $-1,93$ & 3,29 & 0,5472 & 0,67421 \\
AUD & 0,00 & 1,00 & 0,4194 & 0,49434 \\
\hline
\end{tabular}

The descriptive statistics in Table 1 show that the level of Corporate Social Responsibility Disclosure within the companies that have been registered in the Indonesian Stock Exchange based on the GRI G4 Index has been low namely 0.083 from the overall GRI components. This finding shows that the Corporate Social Responsibility of the companies in Indonesia toward the social and the environmental issues have been very low. On the other hand, the descriptive statistics on the CEOs, namely the Economics and Business-Related Educational Background, Functional Experience, Gender and Age show various mean score. Most of the CEOs within the companies in Indonesia are dominated by the graduates of Economics and Business as having been shown the mean score of EDU variable namely 0.6523 . Then, most of the CEOs within the companies in Indonesia are dominated by the Throughput (Shareholder-
Oriented) Functional Experience rather than the Output (Stakeholder-Oriented) Functional Experience as having been showed by the mean score of the FUNCEXP variable namely 0.2115 . Next, the number of female CEOs is still low as having been shown by the mean score of the FEM variable namely 0.0251 . Last but not the least, the mean score of the AGE variable is 52.19 years old with the youngest CEO is 30 years old and the eldest CEO is 76 years old.

The variable Ownership Concentration (OWC) shows that the share ownership within the companies in Indonesia tends to be concentrated, as having been shown by the mean score of the variable OWC namely 0.4937 with the minimum score 0.09 and the maximum score 0.95 . This finding is consistent with the results of the study by Claessens et al. (2000), which show that Indonesia is one of the countries that have the concentrated share 
ownership. Then, the results of the descriptive statistics for the control variables are various. The company size, shown by the variable Ln_SIZE namely the natural logarithm from the total asset, is 12.099 with the minimum value 7.83 and the maximum value 14.73 . Next, the mean score of the Leverage variable that has been measured by using the debt to equity ratio is 0.5472 and this mean score implies that the debt to equity ratio tends to be small. Furthermore, the mean score of the Return on Total Asset variable is 0.0348 and such mean score implies that the Return on Total Asset tends to be low. The reason might be that the total asset that the sampled companies have tend to be big. Last but not the least, the mean score of the audit quality as having been shown by the AUD variable is 0.4194 . This mean score implies that there are still plenty of companies that have been registered in the Indonesian Stock Exchange has not been audited by the Big Four.

The results of the hypothesis test for model $1-5$ is performed by using the regression model 1-5. The summary for the results of the regression test for model 1-5 might be consulted in Table 2.

\section{The Influence of Economics and Business-}

\section{Related Educational Background on the}

\section{Corporate Social Responsibility Disclosure}

The first hypothesis until the fourth hypothesis aims at testing the influence of the CEO characteristics, namely Economics and Business-Related Educational Background $(\mathrm{H} 1)$, Functional Experience $(\mathrm{H} 2)$, Gender $(\mathrm{H} 3)$ and Age $(\mathrm{H} 4)$, on the level of CSR Disclosure of the company. The results of the regression analysis for the $\mathrm{H} 1$ test until the $\mathrm{H} 4$ test are summarized in model 1 Table 2.

As having been explained, the first hypothesis $(\mathrm{H} 1)$ aims at testing the influence of Economics and Business-Related Educational Background of the CEO on the CSR Disclosure of the company. The summary of the $\mathrm{H} 1$ test in model 1 Table 2 shows the insignificant results, which automatically does not support the first hypothesis. Specifically, the results of the regression output within the hypothesis test with the coefficient of the variable EDU $(\mathrm{H} 1)$ show that the coefficient is 0.002 and the probability is 0.692 (insignificant). Thus, it might be concluded that the Economics and BusinessRelated Educational Background of the CEO does not influence the CSR Disclosure of the Company. These results are not in accordance to the results of the study by Manner (2010), which concludes that the Economics and Business-Related Educational Background has negative influence on the CSR Disclosure of a company. The CEO who has the Economics and Business-Related Educational Background will be more profit-oriented and will tend to less disclose the Corporate Social Responsibility. Similarly, in their study Frank et al. (1993) have found that the educational background of an individual will shape the belief and the values of the individual. The CEO who comes from the Economics and Business-Related Educational Background will be influenced by the perception that has been established during the period of the study and the perception will certainly be more profit oriented. The insignificant results within the study is possibly influenced by the 
Tabel 2 Results of Regression Test for Model 1 - 5

\begin{tabular}{|c|c|c|c|c|c|c|c|c|c|c|c|}
\hline \multirow[t]{2}{*}{ Variable } & \multirow{2}{*}{$\begin{array}{l}\text { Predicted } \\
\text { sign }\end{array}$} & \multicolumn{2}{|c|}{ Model 1} & \multicolumn{2}{|c|}{ Model 2} & \multicolumn{2}{|c|}{ Model 3} & \multicolumn{2}{|c|}{ Model 4} & \multicolumn{2}{|c|}{ Model 5} \\
\hline & & Coefficient & Prob. & Coeficient & Prob & Coeficient & Prob & Coeficient & Prob & Coeficient & Prob \\
\hline EDU & - & 0,002 & 0,692 & & & & & & & & \\
\hline FUNGEXP & + & 0,044 & $0,000^{* * *}$ & & & & & & & & \\
\hline FEM & + & 0,003 & 0,842 & & & & & & & & \\
\hline AGE & + & $-0,006$ & 0,842 & & & & & & & & \\
\hline LOG_SIZE & + & 0,019 & $0,000^{* * *}$ & & & & & & & & \\
\hline LEV & + & 0,030 & 0,284 & & & & & & & & \\
\hline $\mathrm{ROA}$ & + & 0,003 & 0,379 & & & & & & & & \\
\hline AUD & + & $-0,013$ & $0,013^{* *}$ & & & & & & & & \\
\hline EDU & - & & & $-0,003$ & 0,809 & & & & & & \\
\hline OWC & - & & & $-0,044$ & $0,029^{* *}$ & & & & & & \\
\hline OWC*EDU & + & & & 0,014 & 0,574 & & & & & & \\
\hline LOG_SIZE & + & & & 0,019 & $0,000^{* * *}$ & & & & & & \\
\hline LĒV & + & & & 0,052 & $0,087^{\star}$ & & & & & & \\
\hline ROA & + & & & 0,005 & 0,215 & & & & & & \\
\hline AUD & + & & & $-0,007$ & 0,220 & & & & & & \\
\hline FUNGEXP & + & & & & & 0,025 & $0,080^{*}$ & & & & \\
\hline OWC & - & & & & & $-0,030$ & $0,019^{* *}$ & & & & \\
\hline OWC*FUNGEXP & - & & & & & 0,038 & 0,176 & & & & \\
\hline LOG_SIZE & + & & & & & 0,019 & $0,000^{* * *}$ & & & & \\
\hline LEV & + & & & & & 0,041 & 0,135 & & & & \\
\hline ROA & + & & & & & 0,003 & 0,352 & & & & \\
\hline AUD & + & & & & & $-0,012$ & $0,018^{* *}$ & & & & \\
\hline
\end{tabular}




\begin{tabular}{|c|c|c|c|c|c|c|c|c|c|c|c|}
\hline \multirow[t]{2}{*}{ Variable } & \multirow{2}{*}{$\begin{array}{l}\text { Predicted } \\
\text { sign }\end{array}$} & \multicolumn{2}{|c|}{ Model 1} & \multicolumn{2}{|c|}{ Model 2} & \multicolumn{2}{|c|}{ Model 3} & \multicolumn{2}{|c|}{ Model 4} & \multicolumn{2}{|c|}{ Model 5} \\
\hline & & Coefficient & Prob. & Coeficient & Prob & Coeficient & Prob & Coeficient & Prob & Coeficient & Prob \\
\hline FEM & + & & & & & & & 0,014 & 0,560 & & \\
\hline OWC & - & & & & & & & $-0,032$ & $0,015^{\star *}$ & & \\
\hline OWC*FEM & - & & & & & & & $-0,029$ & 0,596 & & \\
\hline LOG_SIZE & + & & & & & & & 0,018 & $0,000^{* * *}$ & & \\
\hline LEV & + & & & & & & & 0,052 & 0,089 & & \\
\hline ROA & + & & & & & & & 0,005 & 0,188 & & \\
\hline AUD & + & & & & & & & $-0,007$ & 0,218 & & \\
\hline AGE & + & & & & & & & & & $-0,001$ & 0,290 \\
\hline OWC & - & & & & & & & & & $-0,130$ & $0,016^{* *}$ \\
\hline OWC*AGE & - & & & & & & & & & 0,002 & 0,240 \\
\hline LOG_SIZE & + & & & & & & & & & 0,018 & $0,000^{* * *}$ \\
\hline LEV & + & & & & & & & & & 0,054 & 0,071 \\
\hline ROA & + & & & & & & & & & 0,005 & 0,176 \\
\hline AUD & + & & & & & & & & & $-0,006$ & 0,260 \\
\hline $\mathrm{N}$ & & \multicolumn{2}{|c|}{279} & \multicolumn{2}{|c|}{279} & \multicolumn{2}{|c|}{279} & \multicolumn{2}{|c|}{279} & \multicolumn{2}{|c|}{279} \\
\hline$R^{2}$ & & \multicolumn{2}{|c|}{0,439} & \multicolumn{2}{|c|}{0,338} & \multicolumn{2}{|c|}{0,450} & \multicolumn{2}{|c|}{0,337} & \multicolumn{2}{|c|}{0,339} \\
\hline Adj. $R^{2}$ & & \multicolumn{2}{|c|}{0,422} & \multicolumn{2}{|c|}{0,321} & \multicolumn{2}{|c|}{0,436} & \multicolumn{2}{|c|}{0,320} & \multicolumn{2}{|c|}{0,322} \\
\hline$F$-value & & \multicolumn{2}{|c|}{$26,421^{* * *}$} & \multicolumn{2}{|c|}{$19,769^{* * *}$} & \multicolumn{2}{|c|}{$31,564^{* * *}$} & \multicolumn{2}{|c|}{$19.676^{* * *}$} & \multicolumn{2}{|c|}{$19,898^{* * *}$} \\
\hline
\end{tabular}

${ }^{* * *}$ significant on level $1 \%{ }^{* *}$ significant on level $5 \%{ }^{*}$ significant on level 10 
educational process within the classroom: the educational process within the classroom has not been able to shape the individual perception of the CEO toward the strategic decisions within the company during the period of the study. The individual perception of the CEO is more influenced by his or her personal experience from the career degree in the previous position. The experience of the CEO, which might be longer than the educational period, will possibly influence his or her perception toward the strategic decision of the company.

\section{The Influence of the Functional Experience on the Corporate Social Responsibility}

The influence of the Output Functional Experience of the CEO toward the CSR Disclosure is shown by the results of the regression test in model 1 Table 2 . The results of the hypothesis regression test for the variable FUNCEXP $(\mathrm{H} 2)$ in model 1 show that the coefficient of the variable is 0.044 while the probability value of the variable is 0.000 (significant). These results support the second hypothesis $(\mathrm{H} 2)$ that has been proposed in the study. Thus, the results of the study are in accordance to the results of the study by Manner (2010), which has found the positive influence from the Output Functional Experience of the CEO to the CSR Disclosure of the company. Output Functional Experience refers to the individual experience in the domain of marketing, sale and product research and development and also in the domain that has been mostly associated to the stakeholders (Hambrick \& Mason, 1984). The CEO who has the Output Functional Experience will understand the interest of the stakeholders better. The job experience of such CEO, which has been more associated with the stakeholders, will make him or her more care about the aspects that are related to the Corporate Social Responsibility of the company. The significant results of the $\mathrm{H} 2$ test strengthens the possibility that the individual perception is more influenced by the Functional
Experience of the CEO in comparison to the Educational Background.

\section{The Influence of Gender on the Corporate Social Responsibility Disclosure}

The test for the third hypothesis $(\mathrm{H} 3)$ has shown insignificant results. According to the summary in model 1 Table 2, the regression output of the third hypothesis test for the variable FEM $(\mathrm{H} 3)$ shows that the coefficient of the variable FEM is 0.030 while the probability value of the variable FEM is 0.0842 (insignificant). These results are in contradiction to the results of the study by Manner (2010), which show that the Female CEO brings about positive influence on the CSR Disclosure of a company. A Female CEO might increase the CSR Disclosure Disclosure of a company. In their study, Post et al. (2011) have found that women have higher tendency to be more caring about the environmental issues than men do. However, the results of the study show that the presence of Female CEO does not influence the CSR Disclosure of a company. Such insignificant results might be caused by the influence from the composition of other Chief Executive Directors, which might be occupied by male. Not to mention, the presence of Female CEO on the top management is still rare. This situation is depicted by the descriptive statistics of the study, which show that the companies that have been directed by the Female CEOs are only 0.0251 from the overall samples. The composition of the top management that has been dominated by the Male CEOs might influence the decision of the Female CEO with regards to the strategic policy of the company. Konrad et al. (2008) have found that at least there should be three Female CEOs in order to voice the female problems and the female role within a company. Then, the other possibility is that the individual perception of the Female CEO is more influenced by the Functional Experience from the prior career degree and consequently the 
Female CEO will tend to abandon the Corporate Social Responsibility Disclosure.

\section{The Influence of Age on the Corporate Social Responsibility Disclosure}

The test for the fourth hypothesis $(\mathrm{H} 4)$ shows the insignificant results. The results of the regression output for the variable AGE in model 1 Table 2 show that the coefficient of the variable $A G E$ is -0.006 while the probability value of the variable AGE is 0.842 (insignificant). These results show that the Age of the CEO does not influence the CSR Disclosure of the company. The Old CEO does not expose any influence on the Corporate Social Responsibility Disclosure. The reason might be that the Old CEO might not have high sense of moral assessment. Most of the Old CEOs are the founders of the companies. Thus, their perception might have been established by the experience that they have during the establishment of the companies. As a result, they might tend to abandon the Corporate Social Responsibility Disclosure.

\section{The Moderation by the Ownership}

Concentration toward the Influence of the CEO Characteristics on the Corporate Social Responsibility Disclosure

The test for the moderation by the Ownership Concentration toward the influence of CEO Characteristics on the CSR Disclosure has shown the results that do not support the hypothesis $\mathrm{H} 5 \mathrm{a}$ until the hypothesis $\mathrm{H} 5 \mathrm{~d}$. These results might be consulted from model 2 - 5 in Table 2. Model 2 displays the results of the test for the moderation by the Ownership Concentration toward the influence of the Economics and Business-Related Educational Background on the CSR Disclosure of the company. The results show that the coefficient value of the variable OWC*EDU is 0.014 while the probability value of the variable OWC*EDU is 0.574 (insignificant). Then, model 3 displays the results of the test for the moderation by the Ownership Concentration toward the influence of the Functional Experience on the CSR Disclosure of the company. The results in model 3 show that the coefficient value of the variable OWC*FUNCEXP is 0.038 while the probability value of the variable OWC*FUNCEXP is 0.176 (insignificant). Next, model 4 displays the results of the test for the moderation by the Ownership Concentration toward the influence of the Gender on the Corporate Social Responsibility of the Company. The results in model 4 show that the coefficient value of the variable OWC*FEM is 0.029 while the probability value of the variable OWC*FEM is 0.596 (insignificant). Last but not the least, model 5 displays the results of the test for the moderation by the Ownership Concentration toward the influence of the Age on the Corporate Social Responsibility Disclosure. The results in model 5 show that the coefficient value of the variable $O W C^{*} A G E$ is 0.002 while the probability vale of the variable $O W C^{*} A G E$ is 0.240 (insignificant).

As having been explained, the results of the test from model 2 until model 5 in table 2 show that the Ownership Concentration does not moderate the influence of CEO Characteristics, namely Economics and Business-Related Educational Background, Functional Experience, Gender and Age, on the Corporate Social Responsibility Disclosure. In relation to the statement, there might be several causes that lie behind the situation. First, it might be possible that the major shareholder is the company itself. There is a possibility that the company displays a dispersed-type ownership. Second, it might be possible that the major shareholders interfere the managerial decisions in order to benefit themselves. The second possibility usually takes place in familybased companies and does not take place in all companies with concentrated-type ownership. These possibilities are not analysed further in the study due to the limitations on the data of the companies that have been owned by the major shareholders and the data of the companies that have been based on the family 
ownership. Not to mention, the scope of the present study is on the first-hand ownership (the direct ownership).

\section{CONCLUSIONS, LIMITATIONS AND SUGGESTIONS}

The study aims at testing the influence of the CEO Characteristics on the CSR Disclosure of the companies with the concentrated ownership condition. In a more specific manner, the study aims at testing the moderation of the Ownership Concentration toward the influence of the CEO Characteristics on the CSR Disclosure of a company. For the company with the concentrated ownership condition, the major shareholders will dominate the decision-making process that the CEO leads in order to benefit themselves

The results of several tests that have been conducted in the study show that the Characteristic of the CEO that has influence on the CSR Disclosure is the Output Functional Experience. The other characteristics, namely Economics and Business-Related Educational Background, Gender and Age, does not influence the Corporate Social Responsibility Disclosure. The reason might be that the Functional Experience that might have been established for years will shape the individual perception toward the Corporate Social Responsibility rather than the Economics and Business-Related Educational Background, Gender and Age. Then, the results of the test for the moderation by the Ownership Concentration toward the influence of the CEO Characteristics on the CSR Disclosure show that the companies with the concentrated-type ownership do not dominate the decision-making process by the CEO in terms of Corporate Social Responsibility Disclosure. The reason might be that the company itself might not have the concentrated-type ownership. In addition, there might be an interference from the major shareholders toward the managerial decision under the effort of benefitting the shareholders' interest. The second possibility takes place only in the family-based companies and the does not take place in all companies with concentratedtype ownership.

Despite the results, the present study still suffers from several limitations. The first limitation is that within the study the researcher does not test the type of share ownership within a company. The share ownership of a company might be majority owned by another company or majority owned by a family. The companies which shares have been majority owned by another company might not have the concentrated-type ownership. On the contrary, the companies which shares have been majority owned by a family might suffer from the interference by the family members within the decision-making process. The interference takes place because the family members would like to benefit themselves through the possession of the majority shares. With regards to the two situations, in the present study the researcher does not analyse the type of the share ownership because the data to that end are unavailable. Consequently, the analysis within the study is limited to the first-hand ownership (the direct ownership). Therefore, the implication of the present study for the future research in the similar topic is that there should be an analysis toward the second-hand ownership (the indirect ownership) in addition to the first-hand ownership (the direct ownership) of a company. Then, the second limitation is that within the study the researcher only relies on one measurement standards, namely the GRI, for measuring the level of CSR Disclosure within a company. Departing from the second limitation, it is expected that the future researcher in the similar topic might rely on more than one measurement standards and thus compare these standards within the analysis.. 


\section{REFERENCES:}

Alonso-Almeida, M. D. M., Fernández De Navarrete, F. C., \& Rodriguez-Pomeda, J. 2015. Corporate social responsibility perception in business students as future managers: A multifactorial analysis. Business Ethics, 24(1), 1-17. https://doi.org/10.1111/beer.12060

Baumann-Pauly, D., Wickert, C., Spence, L. J., \& Scherer, A. G. 2013. Organizing Corporate Social Responsibility in Small and Large Firms: Size Matters. Journal of Business Ethics, 115(4, SI), 693-705.

Beal, R. M., \& Yasai-Ardekani, M. 2000. Performance Implications of Aligning CEO Functional Experiences with Competitive Strategies. Journal of Management, 26(4), 733-762.

Boone, C., Brabander, B. De, \& Witteloostuijn, A. van. 1999. The Impact of Personality on Behavior in Five Prisoner's Dilemma Games. Journal of Economic Psychology, 20(3), 343-377.

Boulouta, I., \& Pitelis, C. N. 2014. Who Needs CSR? The Impact of Corporate Social Responsibility on National Competitiveness. Journal of Business Ethics, 119(3), 349-364.

Carney, R. W., \& Hamilton-Hart, N. 2015. What Do Changes in Corporate Ownership in Indonesia Tell Us? Bulletin of Indonesian Economic Studies, 51(1), 123-145. https://doi.org/10.1080/00074918.2015.1016570/Accessed: 03-27-2019 05:12 UTC

Caroll, R. J., Primo, D. M., \& Ritcher, B. K. 2016. Using Item Response Theory to Improve Measurement in Strategic Management Research: An Aplication to Corporate Social Responsibility. Strategic Management Journal, 37, 66-85.

Carpenter, M. A., Geletkancz, M. A., \& Sanders, W. G. 2004. Upper echelons research revisited: Antecedents, elements, and consequences of top management team composition. Journal of Management.

Chang, Y. K., Oh, W.-Y., Jung, J. C., \& Lee, J.-Y. 2012. Firm Size and Corporate Social Performance. Journal of Leadership \& Organizational Studies, 19(4), 486-500.

Chapple, W., \& Moon, J. 2005. Corporate Social Responsibility (CSR) in Asia: A Seven-Country Study of CSR Web Site Reporting. Business \& Society, 44(4), 415-441.

Choi, B. B., Lee, D., \& Park, Y. 2013. Corporate Social Responsibility , Corporate Governance and Earnings Quality : Evidence from Korea, 21(5), 447-467. https://doi.org/10.1111/corg.12033/Accessed: 10-07-2017 08:31 UTC

Claessens, S., Djankov, S., \& Lang, L. H. . 2000. The separation of ownership and control in East Asian Corporations. Journal of Financial Economics. https://doi.org/https://doi.org/10.1016/S0304405X(00)00067-2/Accessed: 10-07-2017 11:26 UTC

Custódio, C., \& Metzger, D. 2014. Financial expert CEOs: CEO's work experience and firm's financial policies. Journal of Financial Economics, 114(1), 125-154.

Dam, L., \& Scholtens, B. (2013). Ownership Concentration and CSR Policy of European Multinational Enterprises. Journal of Business Ethics, 118, 117-126. https://doi.org/10.1007/s10551-012-15741/Accessed: 10-07-2017 10:26 UTC

Diamantopoulos, A., Schlegelmilch, B. B., Sinkovics, R. R., \& Bohlen, G. M. 2003. Can socio-demographics still play a role in profiling green consumers? A review of the evidence and an empirical investigation. Journal of Business Research.

Dias, A., Rodriguez, L. L., \& Craig, R. 2017. Corporate Governance Effects on Social Responsibility Disclosures. Australasian Accounting, Business and Finance Journal, 11(2), 3-22 
Fabrizi, M., Mallin, C., \& Michelon, G. 2014. The Role of CEO???s Personal Incentives in Driving Corporate Social Responsibility. Journal of Business Ethics, 124(2), 311-326.

Faccio, M., Lang, L. H. P., \& Young, L. 2001. Dividends and Expropriation. American Economic Review, 91(1), 54-78.

Fernandez-Feijoo, B., Romero, S., \& Ruiz, S. 2014. Commitment to Corporate social responsibility measured through global reporting initiative reporting: Factors affecting the behavior of companies. Journal of Cleaner Production, 81, 244-254. Retrieved from https://doi.org/10.1016/j.jclepro.2014.06.034/Accessed: 10-07-2017 09:24 UTC

Forte, A. 2004. Antecedents of Managers Moral Reasoning. Journal of Business Ethics, 51(4), 313-347.

Frank, B., \& Schulze, G. G. 2000. Does economics make citizens corrupt? Journal of Economic Behavior \& Organization, 43(1), 101-113.

Frank, R. H., Gilovich, T., \& Regan, D. T. 1993. Does Studying Economics Inhibit Cooperation? Journal of Economic Perspectives, 7(2), 159-171.

Hambrick, D. C. 2007. Editor's Forum Upper Echelons Theory: An Update. Academy of Managerial Review, 32(2), 334-343.

Hambrick, D. C., \& Mason, P. a. 1984. Upper Echelons : The Organization as a Reflection of Its Top Managers. Management, 9(2), 193-206.

Haniffa, R. M., \& Cooke, T. E. 2005. The Impact of Culture and Governance on Corporate Social Reporting. Journal of Accounting and Public Policy, 24, 391-430.

Holder-Webb, L., Cohen, J. R., Nath, L., \& Wood, D. 2009. The Supply of Corporate Social Responsibility Disclosures Among U . S . Firms. Journal of Business Ethics, 84(4), 497-527.

Hooghiemstra, R. 2000. Corporate Communication and Impression Management-New Perspectives Why Companies Engage In Corporate Social Reporting. Journal of Business Ethics, 28, 55-68.

Huang, H. W., Rose-Green, E., \& Lee, C. C. 2012. CEO age and financial reporting quality. Accounting Horizons, 26(4), 725-740.

Huang, S. K. 2012. The Impact of CEO Characteristics on Corporate Sustainable Development. https://doi.org/10.1002/csr.1295

Jaggi, B., \& Tsui, J. 2007. Insider Trading, Earnings Management and Corporate Governance: Empirical Evidence Based on Hong Kong Firms. Journal of International Financial Management \& Accounting, 18(3), 192-222.

Jain, T., Aguilera, R. V., \& Jamali, D. 2014. Corporate Stakeholder Orientation in an Emerging Country Context: A Longitudinal Cross Industry Analysis. Journal of Business Ethics, 143(4), 701-719.

Jamali, D., \& Karam, C. 2016. Corporate Social Responsibility in Developing Countries as an Emerging Field of Study, 00,1-30.

Jamali, D., \& Neville, B. 2011. Convergence Versus Divergence of CSR in Developing Countries: An Embedded Multi-Layered Institutional Lens. Journal of Business Ethics, 102(4), 599-621.

Jones, T., Agle, B., \& Jenifer Ehreth. 1990. Graduate Business Education and the Moral Development of MBA Students: Theory and Preliminary Results. In The International Association of Business and Society.

Kansal, M., Joshi, M., \& Batra, G. S. 2014. Determinants of corporate social responsibility disclosures: Evidence from India. Advances in Accounting, 30(1), 217-229.

Khlif, H., \& Souissi, M. 2010. The determinants of corporate disclosure: a meta analysis. International Journal of Accounting \& Information Management, 18(3), 198-219.

Kim, H. J., \& Yoon, S. S. 2008. The Impact of Corporate Governance on Earnings Management in Korea. Malaysian Accounting Review, 7(1), 43-59.

Kleinrichert, D., Tosti-Kharas, J., Albert, M., \& Eng, J. P. 2013. The Effect of a Business and Society Course on Business Student Attitudes Toward Corporate Social Responsibility. Journal of Education for Business, 88(4), 230-237.

Klineberg, S. L., McKeever, M., \& Rothenbach, B. 1998. Demographic predictors of environmental concern : It does make a difference how it's measured. Social Science Quarterly (University of Texas Press), 79(4), 734-753. 
KPMG. 2011. KPMG International Responsibility Reporting 2011. KPMG International. Retrieved from https://www.kpmg.com/PT/pt/lssuesAndlnsights/Documents/corporateresponsibility2011.pdf\%5Cnwww.kpmg.com/Accessed: 10-07-2017 03:22 UTC

Kyun, Y., Oh, C. W., Hyun, J., Myoung, P., \& Jang, G. 2015. Exploring the Relationship Between Board Characteristics and CSR: Empirical Evidence from Korea. Journal of Business Ethics. https://doi.org/10.1007/s10551-015-2651-z

L.A. Philips. 1999. Green Attitude. American Demographics, 21(4), 46-47.

Leuz, C., Nanda, D., \& Wysocki, P. D. 2003. Earnings Management and Investor Protection: An International Comparison. Journal of Financial Economics, 69(3), 505-527.

Manner, M. H. 2010. The Impact of CEO Characteristics on Corporate Social Performance. Journal of Business Ethics, 93, 53-72.

McCabe, A. C., Ingram, R., \& Dato-On, M. C. (2006). The Business of Ethics and Gender. Journal of Business Ethics, 64(2), 101-116.

Muttakin, M. B., \& Khan, A. 2014. Determinants of corporate social disclosure: Empirical evidence from Bangladesh. Advances in Accounting, 30(1), 168-175.

Ng, E. S., \& Burke, R. J. 2010. Predictor of business students' Attitudes toward sustainable business practices. Journal of Business Ethics, 95(4), 603-615.

Nicholas, A. J., \& Sacco, S. 2017. People, Planet, Profit: Benefit and B Certified Corporations - Comprehension and Outlook of Business Students. Academy of Business Research Journal, 3, 18-31.

Oeyono, J., Samy, M., \& Bampton, R. 2011. An examination of corporate social responsibility and financial performance. Journal of Global Responsibility, 2(1), 100-112. https://doi.org/10.1108/20412561111128555

Oh, W.-Y., Li, Z., \& Park, S. 2016. The Effects of CEO Charachteristics and Incentives on Corporate Social Responsibility. Corporate Social Responsibility, 162-182.

Park, I. B., \& Ghauri, P. N. 2014. Determinants influencing CSR practices in small and medium sized MNE subsidiaries : A stakeholder perspective. Journal of World Business.

Peng, C.-W., \& Yang, M.-L. 2014. The Effect of Corporate Social Performance on Financial Performance: The Moderating Effect of Ownership Concentration. Journal of Business Ethics, 123(1), 171-182.

Post, C., Rahman, N., \& Rubow, E. 2011. Green Governance: Boards of Directors' Composition and Environmental Corporate Social Responsibility. Business \& Society, 50(1), 189-223.

Reverte, C. 2009. Determinants of Corporate Social Responsibility Disclosure Ratings by Spanish Listed Firms. Journal of Business Ethics, 88, 351-366.

Ritchie, W., \& Eastwood, K. 2006. Using administrative data to measure the extent to which practitioners work together: "interconnected" care is common in a large cohort of family physicians. Nonprofit Management and Leadership, 17(1).

Schmidt, M. A., \& Cracau, D. 2015. Cross-Country Comparison of the Corporate Social Responsibility Orientation in Germany and Qatar : An Empirical Study among Business Students, (6).

Selten, R., \& Ockenfels, A. 1998. An experimental solidarity game. Journal of Economic Behavior \& Organization, 34(4), 517-539.

Shleifer, A., \& Vishny, R. W. 1997. Survey of Corporate Governance. Journal of Finance, 52(2), 737-783.

Slater, D. J., \& Dixon-Fowler, H. R. 2010. The Future of the Planet in the Hands of MBAs: An Examination of CEO MBA Education and Corporate Environmental Performance. Academy of Management Learning and Education, 9(3), 429-441.

Sun, L., \& Rakhman, F. 2013. CFO Financial Expertise and Corporate Social Responsibility: Evidence from S\&P 500 Companies. International Journal of Law and Management, 55, 161-172.

Sundaram, R. K., \& Yermack, D. L. 2007. Pay Me Later : Inside Debt and Its Role in Managerial Compensation $t$ and Its Role in Managerial Compensation, 62(4), 1551-1588.

Udayasankar, K. 2007. Corporate social responsibility and firm size. Journal of Business Ethics, 83(2), 167-175.

Varma, V. S., Patel, A., \& Naidu, D. 2009. Shareholder Concentration and Discretionary Accruals: Evidence from An Emerging Market. The IUP Journal of Accounting Research and Audit Practices, 8(2), 7-16. 
Walsh, J. P. 1988. Selectivity and Selective Perception: An Investigation of Manager's Belief Structure and Information Processing. Academy of Management Journal, 31(4), 873-896.

Wang, H., Tong, L., Takeuchi, R., \& George, G. 2016. Corporate Social Responsibility: An Overview and New Research Directions (Thematic Issue on Corporate Social Responsibility). Academy of Management Journal, 59(2), 534-544. https://doi.org/1

Wong, A., Long, F., \& Elankumaran, S. 2009. Business students' perception of corporate social responsibility: The United States, China, and India. Corporate Social Responsibility and Environmental Management, 310(September 2009), 299-310.

Wood, D. J. 1991. Corporate Social Performance Revisited. Academy of Management Review, 16(4), 691-718. 